IZA DP No. 8564

Young Entrepreneurs in Rural Africa:

Prevalence, Determinants, Productivity

Paula Nagler

Wim Naudé

October 2014 


\title{
Young Entrepreneurs in Rural Africa: Prevalence, Determinants, Productivity
}

\author{
Paula Nagler \\ MsM, UNU-MERIT/MGSoG, Maastricht University \\ Wim Naudé \\ MSM, UNU-MERIT/MGSoG, Maastricht University \\ and IZA
}
Discussion Paper No. 8564
October 2014

\author{
IZA \\ P.O. Box 7240 \\ 53072 Bonn \\ Germany \\ Phone: +49-228-3894-0 \\ Fax: +49-228-3894-180 \\ E-mail: iza@iza.org
}

Any opinions expressed here are those of the author(s) and not those of IZA. Research published in this series may include views on policy, but the institute itself takes no institutional policy positions. The IZA research network is committed to the IZA Guiding Principles of Research Integrity.

The Institute for the Study of Labor (IZA) in Bonn is a local and virtual international research center and a place of communication between science, politics and business. IZA is an independent nonprofit organization supported by Deutsche Post Foundation. The center is associated with the University of Bonn and offers a stimulating research environment through its international network, workshops and conferences, data service, project support, research visits and doctoral program. IZA engages in (i) original and internationally competitive research in all fields of labor economics, (ii) development of policy concepts, and (iii) dissemination of research results and concepts to the interested public.

IZA Discussion Papers often represent preliminary work and are circulated to encourage discussion. Citation of such a paper should account for its provisional character. A revised version may be available directly from the author. 


\title{
ABSTRACT \\ Young Entrepreneurs in Rural Africa: Prevalence, Determinants, Productivity
}

\begin{abstract}
Africa is not only the poorest and most rural continent, it is also the most youthful continent in terms of population. Given the large number of young job seekers that will enter the labor market over the next decade, we need a better understanding of rural non-farm entrepreneurship, particularly with regard to the role of young adults in this sector. This paper contributes to the literature by providing empirical evidence on (i) the prevalence of enterprises operated by young adults and the contribution they make to rural household income, the (ii) determinants of enterprise operation, and (iii) labor productivity in enterprises operated by young owners. Using the World Bank's recent LSMS-ISA database that covers six countries in Sub-Saharan African, we find that young adults present a lower share of enterprise owners and derive less income from it. Using a Heckman selection model and panel data analysis, we further find that young household head have a lower likelihood of operating and enterprise and if they operate one, these enterprises are less productive than those of older adults. We conclude that policies to support young entrepreneurs in rural Africa should not only focus on creating conditions that attract young adults to start enterprises, but to also enable young entrepreneurs to improve productivity in already existing enterprises. If these enterprises grow and survive, they can provide a part of the growing number of nonfarm jobs that will be needed in Africa's rural areas.
\end{abstract}

JEL Classification: J43, L26, M13, O55, O13, Q12

Keywords: entrepreneurship, labor markets, productivity, rural development, Sub-Saharan Africa, youth employment

Corresponding author:

Wim Naudé

Maastricht School of Management

PO Box 1203

6201 BE Maastricht

The Netherlands

E-mail:w.naude@maastrichtuniversity.nl 


\section{Introduction}

Africa continues to be the poorest and most rural continent, with a high share of people still employed in agriculture, and a large young population. Overall, two-third of the labor force is involved in agriculture, generating one-third of the gross domestic product in SubSaharan Africa (Pye-Smith, 2012). Poverty in rural areas is about one quarter higher than in urban areas (Dercon, 2009; Fox and Pimhidzai, 2013; McArthur, 2014). Furthermore it is the continent with the world's highest share of youth in the working age population and the highest youth population growth rate (Pieters, 2013). The median age in Africa is 18 years, the youngest of all regions (Fox and Pimhidzai, 2013). Around 60 percent of the unemployed in Africa are estimated to be below the age of 30 (Leavy and Smith, 2010) with youth unemployment twice as high as adult unemployment (Pye-Smith, 2012).

Poor, rural and young: with a 3 percent annual growth in labor supply, development in Africa therefore requires employment to be created for an expected 170 million new labor market entrants between 2010 and 2020, mostly young people in rural areas (Bezu and Barrett, 2012; Fox and Pimhidzai, 2013). ${ }^{1}$ With agricultural employment and income declining (Pye-Smith, 2012; Grindling and Newhouse, 2014; Teal, 2014) and in light of changing aspirations of Africa's young people to abandon agriculture (Leavy and Smith, 2010; van der Geest, 2010), ${ }^{2}$ many have put their hopes in the nonfarm sector to find work (Fox and Sohnesen, 2013; Teal, 2014). If sufficient employment cannot be created, the large number of young unemployment adults are a source of concern. Namatovu et al. (2012), Pieters (2013) and Blattmann et al. (2014) have raised concerns about political instability, social unrest, crime and conflict.

Despite this challenge there is still a lack of empirical evidence about the role of young adults in rural non-farm entrepreneurship (e.g. DIAL, 2007; Namatovu et al., 2012). We have limited knowledge about the age structure in the non-farm sector, the determinants of enterprise operation, or the effect of age on labor productivity. More generally this reflects that "there is little youth-specific research on self-employment" in Africa (Pieters, 2013 , p. 20) and that most studies of youth employment have focused on urban areas (DIAL, 2007). This knowledge gap may hinder the formulation of appropriate policies to support young rural entrepreneurs.

The contribution of this paper is to provide an empirical analysis of (i) the prevalence of young adults in the non-farm sector and their contribution to rural household income, (ii) determinants of enterprise operation, and (iii) labor productivity in nonfarm enterprises. We use the World Bank's LSMS-ISA database covering six countries in Sub-Saharan Africa, and use data from Ethiopia, Malawi, Nigeria, and Uganda for our analysis. The paper is based on our related work (Nagler and Naudé, 2014a,b), where we study patterns and determinants of enterprise operation in rural Africa, as well as labor productivity in these enterprises. We extend our previous research by focusing on

1 Urbanization in Africa has not been as rapid as previously estimated and may even slow down. Potts (2012, p. 1382) even cautions that "the evidence from censuses and satellite imagery is increasing that the rate at which many countries are becoming more urban in Sub-Saharan Africa has slowed or is even stagnating".

2 According to Leavy and Smith (2010, p. 3) "the dwindling popularity of agriculture among the younger generation reflects a general trend towards deagranisation in the continent". 
the youth, defined as individuals between 15 and 24 years of age, ${ }^{3}$ and present empirical estimates using a Heckman selection model and panel data analysis. It is the first time, to the best of our knowledge, that this database has been used to investigate youth entrepreneurship in rural Africa.

Our main findings are that (i) young adults present a lower share among entrepreneurs and consequently derive less income from self-employment, (ii) young household heads have a lower likelihood of operating a non-farm enterprise, and (iii) young enterprise owners have a lower labor productivity in their enterprises compared to older cohorts. We conclude that policies should target young adults to help them enter the sector, as well as to support them to improve their business productivity once they operate an enterprise, and shield them from adverse events.

The remainder of the paper is organized as follows. In section 2 we summarize the relevant literature on prevalence, determinants, and productivity of non-farm enterprises. In section 3 we describe the LSMS-ISA database, and outline the methodology used for the analysis. In section 4 we present and discuss our results. The final section concludes.

\section{Literature Review}

We use the term "non-farm enterprises" to refer to small, informal household enterprises in the rural non-farm economy. ${ }^{4}$ They include all non-agricultural activities in rural areas including on-farm (but non-agricultural) activities such as agribusiness, as well as services, trade and retail, tourism, rural industrialization, construction, and mining (Nagler and Naudé, 2014b).

Basic literature exists on the rural non-farm economy in Africa focusing on the prevalence and contribution to household income and on the determinants of rural households' decisions to operate non-farm enterprises. There is a much smaller literature on the performance of these enterprises, and a complete lack of research on the extent and nature of youth involvement in such enterprises. In the rest of this section we provide a concise summary of the existing literature on non-farm entrepreneurship.

\subsection{Prevalence and Contribution}

The position in the existing literature has shifted over time. In earlier thinking on rural development, influenced by the Lewis model of structural change (Lewis, 1954), the rural economy was expected to become less important as a contributor to rural household

\footnotetext{
3 We follow the United Nations' definition of youth, where it is understood as a period of transition from the dependence of childhood to adulthood's independence. We are aware that countries might define the age of youth differently within the national context. However, to be able to present comparable results for statistical consistency across regions, we use the UN definition for all countries in our study.

4 While the majority of non-farm enterprises in rural Africa are small, informal household enterprise, exceptions can be found.
} 
income over time (Lanjouw and Lanjouw, 2001). Urbanization and industrialization have consequently been a focus of development policies since the 1960s with agriculture often repressed (Havnevik et al., 2003). The bulk of empirical studies on enterprises and entrepreneurship in Africa have focused on urban areas (Naudé, 2011).

The fact that non-farm enterprises could potentially be important for rural development has only been recognized from the late 1990s onward, when it became clear that the contribution of the non-farm economy did not decline over time, but instead increased (Reardon et al., 2006; Davis et al., 2010). Today, between 40 and 50 percent of household income in rural Africa originates from non-farm activities (non-farm enterprises and other activities) (Lanjouw and Lanjouw, 2001; Start, 2001; Reardon et al., 2006; Davis et al., 2010; Rijkers and Costa, 2012). The share of household income deriving from non-farm entrepreneurship varies by country. Studies reporting the importance of entrepreneurial income in Sub-Saharan Africa find shares of 20 percent in Ethiopia (1999), 64 percent in Malawi (2004), and 46 and 54 percent in Tanzania and Uganda (2000) (Reardon et al., 2006). Using the Rural Income Generating Activities (RIGA) database, ${ }^{5}$ Davis et al. (2010) find that rural non-farm sources of income contribute more than 50 percent to household income in almost two-third of the countries in the data set.

However, it continues to be unclear whether the non-farm economy's rising importance contributes to rural economic growth and poverty reduction, or whether it is a symptom of stagnation (Davis and Bezemer, 2004, p. 23). The current literature suggests a potentially positive role in poverty reduction (Fox et al., 2013), but assesses it as limited to the extent to which households can access opportunities. For instance, Barrett et al. (2001) identify the existence of entry barriers as limiting the extent to which households can exploit profitable opportunities in the non-farm economy. Hence the question arises whether enterprises are operated due to necessity (being pushed into non-farm entrepreneurship), or whether the households perceive and exploit opportunities in the non-farm economy.

\subsection{Determinants}

Households in rural Africa operate non-farm enterprises due to both push and pull factors, with household capabilities and the institutional environment mediating (Reardon et al., 2006). One of the most important push factors is the high degree of risk in agriculture (Rijkers and Söderbom, 2013). These include both covariate and idiosyncratic shocks, adverse weather conditions (floods, drought) and individual level shocks such as illness or death in the family. In the presence of failures and imperfections in the markets for credit and insurance, risk-averse farm households diversify their income ex-ante in anticipation that a crop may fail, or ex-post in the aftermath of a shock (Ackah, 2013). Rural entrepreneurship may therefore be a form of self-insurance in the face of limited insurance markets. Whether households headed by young adults are more likely to operate such enterprises as a form of self-insurance is a priori unclear: on the one hand they might have

5 The RIGA data set covers around 90,000 observations across Albania, Bangladesh, Bulgaria, Ecuador, Ghana, Guatemala, Indonesia, Madagascar, Malawi, Nepal, Nicaragua, Nigeria, Pakistan, Panama and Vietnam. 
a lower likelihood, as younger heads may be less risk averse or suffer from myopia, and hence be less likely to take out self-insurance. These households may also be able to rely on older relatives and the extended family, and have less own dependents. On the other hand they might have a higher likelihood, as they may be less able to manage the risks of farming, and hence resort to non-farm activities to compensate for this shortcoming.

Additionally, longer-term structural push factors such as surplus labor in households may impact the decision of enterprise operation, as growing families put pressure on fixed parcels of farmland over time (Reardon, 1997; Reardon et al., 2006; Babatunde and Qaim, 2010). To the extent that younger households are smaller, they may therefore be less likely to be structurally pushed into non-farm entrepreneurship. Another push factor can be seasonality: household members may be pushed off-farm in the low season, a situation aggravated by a lack of facilities for inter-temporal arbitrage. As a consequence rural non-farm enterprises often present secondary activities (Lanjouw and Lanjouw, 2001).

Whether rural households operate enterprises may also be due to their desire to utilize business opportunities, so called pull factors into entrepreneurship, for instance in a response to demand in rural areas. In this regard household capabilities and assets, as well as individual characteristics have been found to be crucial to facilitate meeting such demand (Barrett et al., 2001). Household capabilities and assets typically include gender, education, marital status (Abdulai and Delgado, 1999), financial assets (Bhaumik et al., 2011; Ackah, 2013), and the size of the household itself. Age may also be significant for a number of reasons. First, age is a proxy for experience, and therefore important for entrepreneurship. Second, age may also be a proxy for wealth, as older individuals have had time to build up wealth (or inherit it) which can serve as capital or collateral for a business. Hence, we expect that younger adults may be less likely or able to operate an enterprise due to perceiving an opportunity.

Both push and pull factors are also influenced by the features of the local and regional economies and which are mostly exogenous to the household. For instance, the agroclimatic environment determines the extent to which agriculture is productive and/or risky (Reardon, 1997). There is evidence that rural entrepreneurship fares better under favorable agro-climatic conditions (e.g. better rainfall) that are good for agricultural productivity and where other natural resources can be found (Reardon et al., 2006). However, this may also lead to the opposite case, when wages are pushed up in areas with high agricultural productivity and undermine the profitability of non-farm enterprises. In such a case, we expect that young adults with limited experience or knowledge of entrepreneurship as a career, are tempted into wage labor on farms. There is evidence from Nigeria that many young adults are increasingly resorting to wage work on farms (Teal, 2014). The household location further determines the distance from urban areas, ports and markets. Generally distance, but also other determinants of market access such as the quality of roads and utilities, can be important determinants of development in both the farm and non-farm economy of Africa, and of the linkages between the two (Wiggens, 2000; Roepstorff and Wiggens, 2011). 


\subsection{Productivity}

In contrast to the extent, contribution and determinants of non-farm entrepreneurship in rural Africa, less research has been conducted with regard to enterprise productivity. Enterprise productivity refers to how efficiently enterprises transform inputs into outputs. The most frequently used measures are total factor productivity and partial measures such as output per labor unit. Syverson (2011) contains a review of the substantial literature on enterprise productivity, of which the vast majority deals with enterprise performance in developed economies. In these studies, age is an important determinant of enterprise productivity. Most studies find a non-linear relationship, suggesting that enterprises with younger owners or managers are less productive, but as they learn with experience, their enterprises become more productive. However, over time they may get less adept at being entrepreneurial, shift their focus, and be associated with decreased enterprise productivity.

Only a few studies have analyzed enterprise productivity in the African continent. Most of those that do, focus either on formal enterprises or manufacturing enterprises, which tend to be overwhelmingly urban-based. Therefore a huge gap exists in the current literature on the productivity of rural non-farm enterprises, particularly in terms of age and age groups.

For African countries most work has been conducted on the impact of the business environment on enterprise productivity. Various studies, using mainly World Bank data on formal enterprises, find that a poor business environment reduces enterprise productivity and growth. Major studies include Dollar et al. (2005), Arnold et al. (2006), Eifert et al. (2008) and Dethier et al. (2010). Less work has been done on clustering and spatial spill-overs. The only study for rural Africa that has conducted this kind of analysis is Owoo and Naudé (2014). They use geo-referenced rural household data from Ethiopia and Nigeria and find evidence of significant spatial auto-correlation from the productivity levels of enterprises in one location (the enumerator area) on that of closely located enterprises. However, they do not take into consideration whether the age of the enterprise owner matters in this regard.

The remaining studies focus on manufacturing firms in Africa. Rijkers et al. (2010) analyze the productivity of non-farm manufacturing enterprises in rural Ethiopia. The authors find that rural enterprises are less productive than urban ones, and report an output per labor ratio for remote rural enterprises of 0.43 , while it is 0.95 for enterprises in rural towns, and 2.30 for enterprises in urban areas (Rijkers et al., 2010, p. 1282). Furthermore they point out that productivity levels are more dispersed in the case of rural enterprises, and that female-headed enterprises are less productive than maleheaded enterprises. Söderbom and Teal (2004) and Söderbom et al. (2006) find that more productive firms tend to survive longer in Africa. This happens however only in the cases when these enterprises have already attained a certain firm size. Frazer (2005) also finds, using Ghanaian enterprise-level data, that more productive enterprises are more likely to survive compared to less productive ones. Again, these studies do not consider whether young adults perform differently. 
If productivity matters for enterprise survival and growth, we expect that non-farm enterprises in rural Africa have on average a lower likelihood to grow and survive than enterprises in urban areas. And that enterprises of younger owners have a lower likelihood to grow and survive than enterprises of older, more experienced owners.

Summarizing the literature survey, it serves three purposes. First, we provide a general and concise background of the nature, prevalence and contribution of entrepreneurship in rural Africa. Second, we identify the determinants of enterprise operation and productivity. And third, we emphasize the general neglect of research in the area of non-farm entrepreneurship in rural Africa, and particularly with regard to the youth.

\section{Data and Methodology}

In this section we first present the database used, the World Bank's LSMS-ISA data set, and outline second the methodology used in the remainder of the paper.

\subsection{Data}

The World Bank's LSMS-ISA database is the result of nationally representative, crosssectional and longitudinal surveys conducted by the World Bank in collaboration with national statistical offices in various countries in Sub-Saharan Africa. ${ }^{6}$ The surveys cover six countries at the time of writing: Ethiopia, Malawi, Niger, Nigeria, Tanzania and Uganda. Cross-sectional data is currently available for all countries, and panel data for Nigeria, Tanzania and Uganda.

The surveys consist of three parts: a community questionnaire, an agricultural questionnaire and a household questionnaire. The community questionnaire collects community-level information and covers access to public services and infrastructure, social networks, governance, and retail prices. The agricultural questionnaire collects information on crop production, storage and sales, land holdings, farming practices, input use and technology adaption, access to and use of services, infrastructure and natural resources, livestock, and fishery. Finally, the household questionnaire captures household demographics, migration, education, health and nutrition, food consumption and expenditure, non-food expenditure, employment, non-farm enterprises and further income sources, dwelling conditions, durable assets, and participation in projects and programs. All data is furthermore geo-referenced.

Despite its strengths and usefulness, the data set has some weaknesses. A comprehensive analysis of enterprise survival and failure is constrained due to a lack of data on failed enterprises. Furthermore, enterprises are not explicitly tracked over the survey rounds in Tanzania and Uganda. Therefore we cannot follow enterprises to study their individual performance over time, and empirical estimates using duration analysis are not possible.

$\overline{6}$ Additional information on the LSMS-ISA: www.worldbank.org/lsms-isa 
More general, but less precise estimations, are still possible. Following our empirical analysis in the next section, we suggest that in future waves and countries, where the LSMS-ISA surveys is still planned to be conducted, a number of modifications and additions should be made to the questionnaire. Although a full elaboration of these fall outside the scope of the present paper, we can briefly mention some to illustrate the type of current shortcomings we face. First, apart from clearly tracking individual enterprises over the survey rounds, discontinued enterprises should equally be registered and information collected. We suggest to add specific questions to know more about these discontinued enterprises, e.g. when exactly the enterprise was stopped (year and month), and the cause for terminating enterprise operations. Second, we recommend to add modules to the questionnaires that collect information to estimate production functions and technical efficiency, including price information, information about the final product(s) and their prices, wages paid per worker, input costs (intermediate inputs), overhead (transport, security), as well as fixed and working assets employed in the enterprise to know more about their capital intensity. ${ }^{7}$

\subsection{Methodology}

In this section we describe the methodology used in this paper. We address the extent and contribution of rural entrepreneurship through a descriptive analysis of the LSMS-ISA data, wherein we compare young enterprise owners with older age groups. Next we make use of kernel density estimates to describe differences in labor productivity and apply a Heckman selection model and panel data analysis to identify determinants of enterprise operation and to assess the individual, household and location characteristics that have an effect on labor productivity. In the methodology section we present our calculation of labor productivity, as well as the formal notation for the Heckman selection model and the panel data analysis.

\subsubsection{Labor Productivity}

Enterprise productivity refers to how efficiently enterprises transform inputs into outputs. The most frequently used measures are total factor productivity and partial measures such as output per labor unit. In the present case, a lack of data precludes calculation of total factor productivity. Hence we can only calculate labor productivity, a partial productivity measure.

Formally we calculate,

$$
\text { labor productivity }=\frac{\text { average monthly sales }}{\text { number of workers }}
$$

As average monthly sales is not available for all countries, we take total sales during the

7 If not further specified, all tables and figures in this article use the LSMS-ISA database and present calculations by the authors. 
last month of operation in Malawi and Nigeria, and average gross revenues in Uganda. Once labor productivity is calculated, we take the log of labor productivity for our estimates. We take the survey round 2011/12 for Ethiopia, and the survey rounds 2010/11 for Malawi, Nigeria, and Uganda.

We acknowledge that using this productivity measure is an approximation, and likely to be subject to measurement errors in the present context. First, we do not take into account output or profit due to a lack of data. Second, we do not have information about the time-use of workers, and do not know how many hours of work are allocated by each individual to the enterprise. And third, we assume that the self-reported variable itself is imprecise, as most enterprise are informal and do not always record sales or revenues, but provide rough estimates of the business volume. Therefore results have to be interpreted with caution. Due to data availability, this productivity measure is however the best approximation that is currently at hand for this study.

\subsubsection{Heckman Selection Model}

We provide estimates of labor productivity in rural non-farm enterprises. Based on the literature survey, we expect that enterprises owned by young adults are less productive compared to older cohorts. To test this, we estimate a Heckman selection model that accounts for selection effects. We use a cross-sectional sample, where we include data from Ethiopia, Malawi, Nigeria, and Uganda into the regression. We take again the survey round 2011/12 for Ethiopia, and the survey rounds 2010/11 for Malawi, Nigeria, and Uganda.

We make use of a Heckman selection model since the determinants of labor productivity may be subject to selection effects. The motivation for operating an enterprise can determine its subsequent productivity if households are pushed into entrepreneurship due to shocks or risk in farming. In this case we expect that they enter relatively lowrisk, but also low-productive type of activities, depending on their risk-aversion. ${ }^{8}$ If we do not control for this selection effect when estimating the determinants of productivity levels, we might get biased estimates as a result. The Heckman selection model takes into account the probability that a particular household operates a non-farm enterprise, called the selection stage, before estimating the level of labor productivity in the subsequent enterprises, called the outcome stage.

Formally we estimate,

$$
z_{i}^{*}=w_{i} \gamma+u_{i}
$$

representing the selection stage of the model, where $z_{i}^{*}$ is a latent variable corresponding to the "outcome" productivity level, which will only be observed once a household operates a non-farm enterprise, thus $z_{i}=1$ if $z_{i}^{*}>0$ and $z_{i}=0$ if $z_{i}^{*} \leq 0 .\left\{w_{i}\right\}$ is a vector containing the possible determinants of enterprise operation.

8 See also Nagler and Naudé (2014b). 
Once $z_{i}$ is known, the outcome stage, the dependent variable is the log of labor productivity, and can be modeled as,

$$
y_{i}^{*}=x_{i} \beta+\varepsilon_{i}
$$

with $y_{i}=y_{i}^{*}$ if $z_{i}=1$ and $y_{i}$ not observed if $y_{i}=0$.

$\left\{x_{i}\right\}$ is a vector containing possible determinants of labor productivity.

For the selection of the independent variables in the outcome stage we follow the literature on enterprise determinants and productivity. We expect that labor productivity depends on individual characteristics, specifically on age (our main explanatory variable), gender, and education. We further expect that access to credit, the experience of shocks, as well as location have an impact on labor productivity. We also include the firm size to account for enterprise characteristics. ${ }^{9}$

\subsubsection{Panel Data Analysis}

We make use of the panel properties for Nigeria and Uganda to estimate the panel regressions. For Nigeria we have data for four survey rounds: post-planting and postharvest data for the years 2010/11 and 2012/13. Due to a limited questionnaire for the post-harvest interviews, we use the data of the post-planting round only. ${ }^{10}$ In the case of Uganda, we have data for three survey rounds: 2009/10, 2010/11, and 2011/12.

Formally we estimate,

$$
\begin{aligned}
& Y_{e h t}=\mathbf{x}_{e h t}^{\prime} \boldsymbol{\beta}^{1}+\mathbf{w}_{h t}^{\prime} \boldsymbol{\gamma}^{1}+\mathbf{z}_{e h t}^{\prime} \boldsymbol{\delta}^{1}+\lambda_{t}^{1}+u_{e h t}^{1} \\
& \bar{Y}_{e h t}=\overline{\mathbf{x}}_{e h t}^{\prime} \boldsymbol{\beta}^{2}+\overline{\mathbf{w}}_{h t}^{\prime} \boldsymbol{\gamma}^{2}+\overline{\mathbf{z}}_{e h t}^{\prime} \boldsymbol{\delta}^{2}+\lambda_{t}^{2}+\mu_{h}+u_{e h t}^{2} \\
& \overline{\bar{Y}}_{e h t}=\overline{\overline{\mathbf{x}}}_{e h t}^{\prime} \boldsymbol{\beta}^{3}+\overline{\overline{\mathbf{w}}}_{h t}^{\prime} \boldsymbol{\gamma}^{3}+\overline{\overline{\mathbf{z}}}_{e h t}^{\prime} \boldsymbol{\delta}^{3}+\lambda_{t}^{3}+\nu_{h}+u_{e h t}^{3}
\end{aligned}
$$

where $\left\{Y_{\text {eht }}, \bar{Y}_{\text {eht }}, \overline{\bar{Y}}_{\text {eht }}\right\}$ is labor productivity at the enterprise level. The set $\left\{\mathbf{x}_{e h t}^{\prime}, \overline{\mathbf{x}}_{e h t}^{\prime}, \overline{\mathbf{x}}_{e h t}^{\prime}\right\}$ contains vectors of individual characteristics of the enterprise owner at the enterprise level. The set $\left\{\mathbf{w}_{h t}^{\prime}, \overline{\mathbf{w}}_{h t}^{\prime}, \overline{\mathbf{w}}_{h t}^{\prime}\right\}$ contains vectors of household characteristics observed at the household level. Finally, $\left\{\mathbf{z}_{e h t}^{\prime}, \overline{\mathbf{z}}_{e h t}^{\prime}, \overline{\mathbf{z}}_{e h t}^{\prime}\right\}$ is a set of vectors of enterprise characteristics at the enterprise level. Let $\left\{\boldsymbol{\beta}^{j}, \boldsymbol{\gamma}^{j}, \boldsymbol{\delta}^{j}\right\}$ denote the associated vectors of coefficients for equation $j$, where $j=1,2,3$. The $\lambda_{t}^{j}$ are time effects for equation $j, \mu_{h}$ are fixed effects at level $k \in\{h\}, \nu_{h}$ are random effects at level $k \in\{h\}$, and $u_{e h t}^{j}$ are idiosyncratic errors for equation $j$.

For the selection of the independent variables we follow again the literature on enterprise productivity. Including the time dimension, we expect that labor productivity depends on individual characteristics, specifically on age (our main explanatory variable), gender, and

\footnotetext{
9 Summary statistics and definition of the variables can be found in Table 5 and 6 in Appendix B.2.

10 The shock variables are taken from the post-harvest questionnaires due to data availability.
} 
education. We also test the variable migration, indicating if the enterprise owner moved from another district or country to the current place of residence. We further expect that access to credit and the experience of shocks have an impact on labor productivity. We also include the firm size and the number of months an enterprise operates per year to account for enterprise characteristics. ${ }^{11}$

\section{Results}

In this section we present and discuss our empirical findings. In section 4.1 we study the extent and contribution of non-farm enterprises managed by young adults or of households with young heads. In section 4.2 we analyze both the determinants of enterprise operation and the productivity of non-farm enterprises by age category.

\subsection{Prevalence and Contribution}

We present a set of descriptive statistics, where we include the share of young entrepreneurs within the non-farm enterprise sector, and the contribution of selfemployment to total household income by the age of the household head.

Table 1 depicts the shares of enterprise owners by age category. For enterprise owners below the age of 25 the share is always smaller compared to the older age cohorts. The difference is particularly pronounced in Tanzania, where less than 5 percent of all enterprise owners are younger than 25 compared to almost 40 percent in the following age cohort. The difference is also more pronounced in Malawi and Nigeria, while Ethiopia reports a more balanced share of age groups. In the age group 45 and older, the share of households with an enterprise declines again in four out of six countries. This suggests that younger adults are less likely to operate a non-farm enterprise compared to middleage cohorts, confirming our expectation.

Table 1: Prevalence of Non-Farm Enterprises - by Age Category

\begin{tabular}{lrrrr}
\hline Country & Age $<25$ & Age 25 to 34 & Age 35 to 44 & Age $\geq 45$ \\
\hline Ethiopia & 21.53 & 35.97 & 25.45 & 17.05 \\
Malawi & 11.95 & 37.55 & 25.60 & 24.90 \\
Niger & 12.22 & 28.65 & 26.28 & 32.85 \\
Nigeria & 8.50 & 25.89 & 28.77 & 36.84 \\
Tanzania & 4.27 & 39.11 & 33.26 & 23.36 \\
Uganda & 11.84 & 32.09 & 30.34 & 25.72 \\
\hline
\end{tabular}

Notes: Weighted shares; Rural households only.

While young adults present a lower share in enterprise operation, it is important to know which other occupation the youth currently pursues. We find that a high percentage of

$\overline{11}$ The variables migration and months in operation are available for Uganda only. Summary statistics and definition of the variables can be found in Table 7 in Appendix B.3. 
the rural youth is still attending school: 48 percent in Ethiopia, 44 percent in Malawi, 63 percent in Nigeria and 53 percent in Uganda. We also find that wage employment is a rather seldom phenomenon in this age group: 4 percent in Ethiopia, 3 percent in Malawi, 4 percent in Nigeria and 18 percent in Uganda. ${ }^{12}$ Therefore young adults might not be excluded or hindered to enter entrepreneurship, but continue to be in education (building up human capital), or pursuing other opportunities that are more beneficial for them.

Using the RIGA data, we calculate the shares of annual net household income by household activity for four countries in our sample: Malawi 2010/11, Niger 2011, Tanzania 2008/09, and Uganda 2010/11. ${ }^{13}$ Figure 1 shows the share of self-employment towards total household income in four countries by age category.

Figure 1: Contribution of Activity to Total Household Income

(a) Malawi

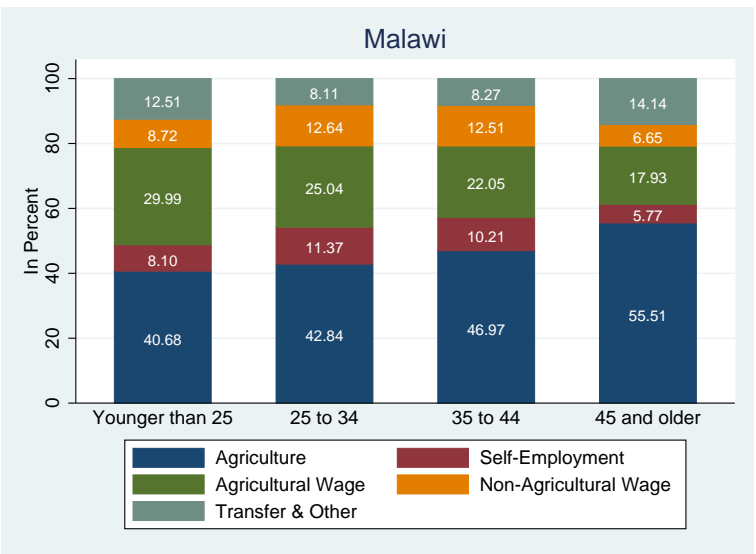

(c) Tanzania

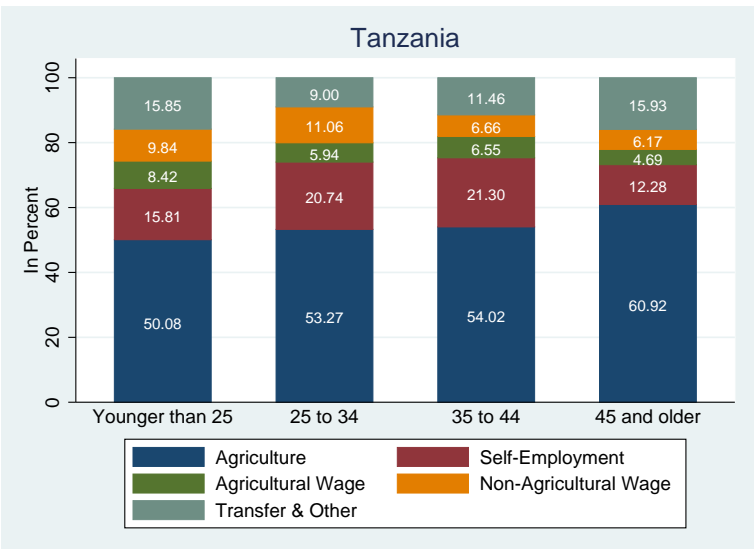

(b) Niger

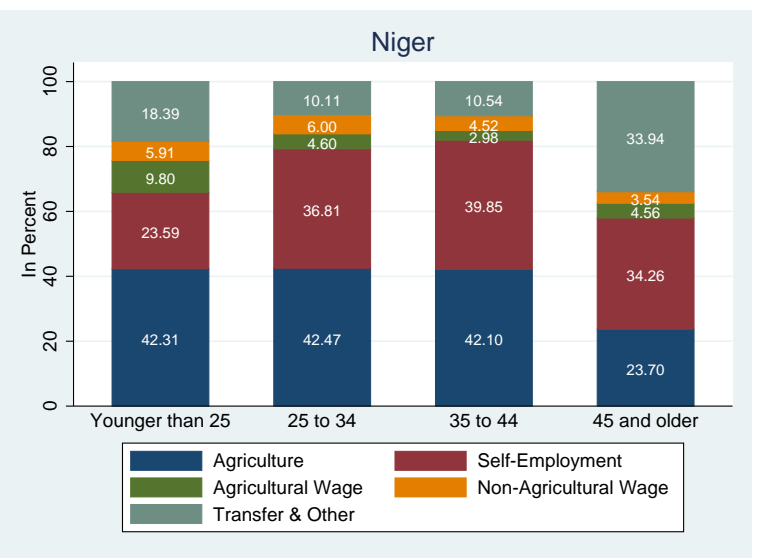

(d) Uganda

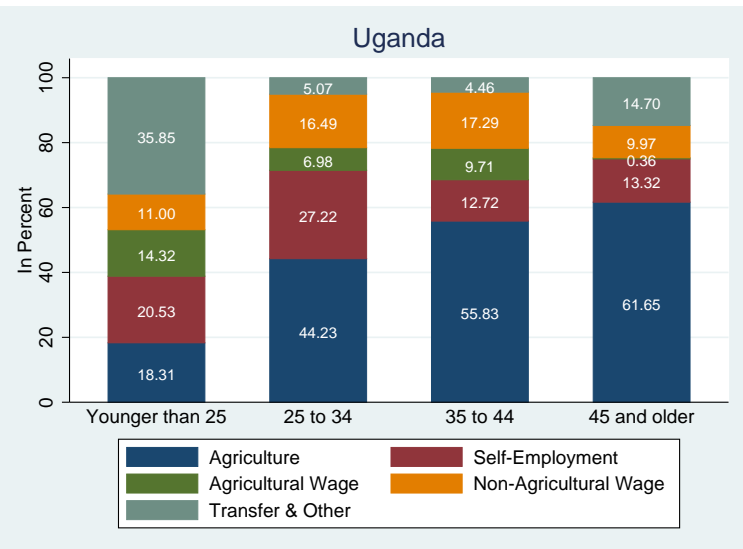

Notes: Authors' own calculations based on the RIGA database; Weighted shares; Rural households only.

${ }^{12}$ Rural areas only. All shares are weighted using survey weights. The time frame for wage employment consists of 12 months for Ethiopia, Malawi, and Uganda, and of 7 days for Nigeria.

${ }^{13}$ Household income is calculated closely following the definition by the International Labor Organization (ILO), where household income consists of all receipts whether monetary or in kind that are received by the household or individual household members at annual or more frequent intervals. It excludes windfall gains and other irregular or onetime receipts. The household income calculated in the RIGA data is based on different sources of income: wage, non-wage, dependent and self-employment, that a household can earn over a well-defined reference period. See also Carletto et al. (2007). 
Self-employment constitutes a smaller share of income for all households with household heads younger than 25 years compared to middle-age household heads. The differences amount to 3 percentage points in Malawi to 13 percentage points in Niger for the age group 25 to 34 , and to -8 percentage points in Uganda to 16 percentage points in Niger for the age group 35 to 44 . The Figure also shows that agricultural wage is more important for young heads compared to the middle-age and older cohorts, and that transfers and other income also have a more pronounced share compared to the middle-age cohorts.

\subsection{Determinants and Productivity}

In this section we investigate labor productivity of non-farm enterprises to determine if enterprises operated by younger enterprise owners show a deviating productivity level. We expect that enterprises operated by older owners are more productive, for example due to experience or better access to finance.

Table 2 gives a first picture of labor productivity by age category, where we take the age of the enterprise owner in rural Ethiopia, Malawi, Nigeria, and Uganda.

Figure 2: Productivity Dispersal - by Age Category

(a) Ethiopia

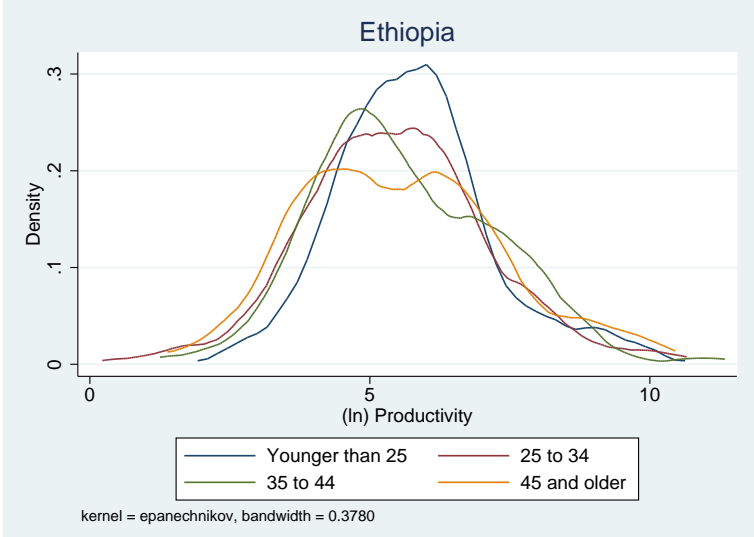

(c) Nigeria

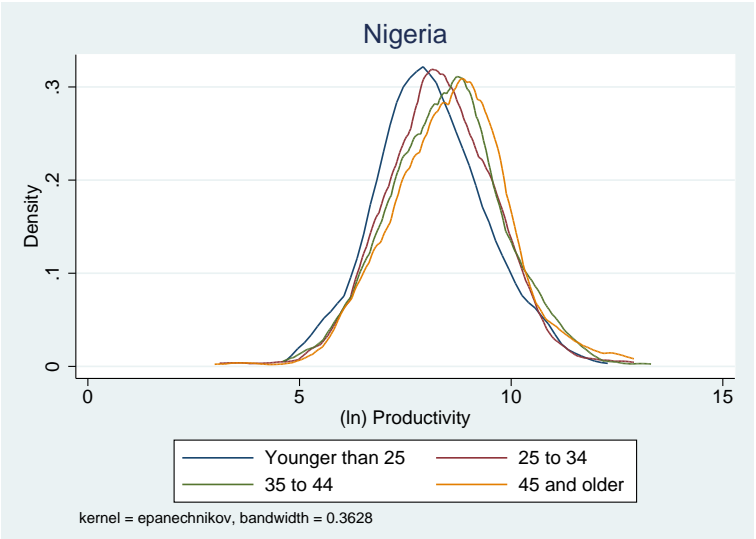

(b) Malawi

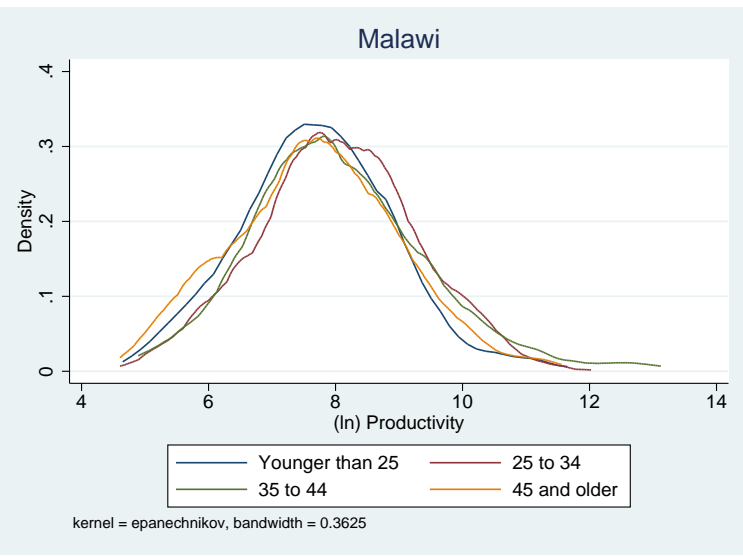

(d) Uganda

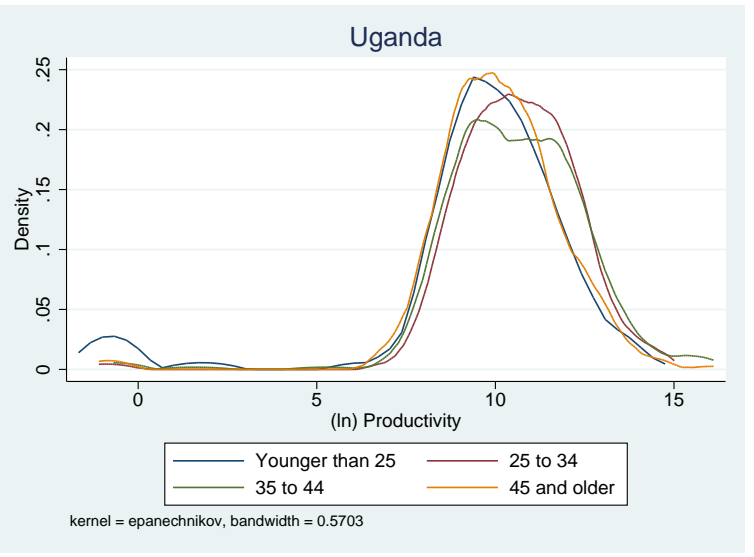

Notes: Rural households only. 
We notice that enterprises owned by a person younger than 25 have a slightly lower labor productivity compared to the older age categories. While the differences are minor in Ethiopia and Malawi, they are more pronounced in rural Nigeria and Uganda.

\subsubsection{Heckman Selection Model}

We continue studying labor productivity using data from these four countries, and also analyze determinants of enterprise operation. We take the complete sample and add the binary variable rural to account for the location of households in rural or urban areas.

Table 2 reports regression results using the Heckman selection model. The first stage, the selection into non-farm entrepreneurship, is reported in the lower part of the table. For the selection stage we make the assumption that the number of adults in a household selects households into this sector as surplus labor is allocated into these enterprises, while it is not associated with productivity as we take a partial productivity measure (sales or revenues per worker). The results in the second stage can be interpreted as though we observed data for all households in the sample. ${ }^{14}$

First we analyze the variable of the selection stage, the determinants of enterprise operation, in the lower part of the regression table. The individual characteristics are taken from the household head, as we include both households with and without enterprises. The coefficients of the selection variable number of adults are significant and positive in Malawi, Nigeria, and Uganda. The age categories do not have an effect on the likelihood of enterprise operation in Ethiopia, but are significant in the three other countries analyzed. Compared to the reference group (young household heads below the age of 25), the middle-age groups have a significantly higher probability of entering non-farm entrepreneurship, ranging from 5 percentage points in Malawi to almost 15 percentage points in Uganda (25 to 34 ) and from 4 percentage points in Malawi to 18 percentage points in Nigeria (35 to 44). If heads are 45 and older, the coefficients are either negative, no longer significant, or positive, but with smaller coefficients compared to the middle-age groups. While we identify a significantly lower likelihood for young adults to operate an enterprise compared to older age cohorts in Malawi, Nigeria and Uganda, young heads are possibly not constraint in entering the non-farm business sector, but are still in education or pursuing opportunities in other areas, for example in wage employment.

Among the other variables in the selection stage, the effect of the variable rural is significant and negative in all countries, indicating a lower probability of entering the non-farm sector if households are located in rural areas. Both the effects of the ability to read and write (in three countries) and access to credit (in Ethiopia and Malawi) are significant and positive. The effect of distance is significant and negative in Ethiopia and Malawi, and the variable shock significant and positive in Malawi, suggesting that households are pushed into entrepreneurship if they experienced a shock.

\footnotetext{
${ }^{14}$ We report coefficients in Table 2, see Tabel 8 in Appendix C for marginal effects of the age categories in the selection stage. In the paper we also state marginal effects when reporting the outcomes of the age categories.
} 
Table 2: Heckman Selection Model

\begin{tabular}{|c|c|c|c|c|}
\hline & $\begin{array}{c}\text { Ethiopia } \\
(1)\end{array}$ & $\begin{array}{c}\text { Malawi } \\
(2)\end{array}$ & $\begin{array}{c}\text { Nigeria } \\
(3)\end{array}$ & $\begin{array}{c}\text { Uganda } \\
(4)\end{array}$ \\
\hline \multicolumn{5}{|l|}{ (ln) Productivity } \\
\hline Rural & $\begin{array}{c}-0.012 \\
(0.35)\end{array}$ & $\begin{array}{c}-0.592^{* * *} \\
(0.11)\end{array}$ & $\begin{array}{c}-0.206^{* * *} \\
(0.07)\end{array}$ & $\begin{array}{l}0.352 \\
(0.33)\end{array}$ \\
\hline Female & $\begin{array}{c}-0.631^{* * *} \\
(0.14)\end{array}$ & $\begin{array}{c}-0.579^{* * *} \\
(0.07)\end{array}$ & $\begin{array}{c}-0.309^{* * *} \\
(0.05)\end{array}$ & $\begin{array}{c}-0.239 \\
(0.15)\end{array}$ \\
\hline Age: 25 to 34 & $\begin{array}{r}-0.090 \\
(0.19)\end{array}$ & $\begin{array}{c}0.251^{* *} \\
(0.10)\end{array}$ & $\begin{array}{l}0.107 \\
(0.10)\end{array}$ & $\begin{array}{l}0.532^{*} \\
(0.27)\end{array}$ \\
\hline Age: 35 to 44 & $\begin{array}{r}-0.051 \\
(0.19)\end{array}$ & $\begin{array}{c}0.307^{* * *} \\
(0.12)\end{array}$ & $\begin{array}{l}0.113 \\
(0.10)\end{array}$ & $\begin{array}{c}0.557^{* *} \\
(0.27)\end{array}$ \\
\hline Age: 45 and older & $\begin{array}{l}0.234 \\
(0.24)\end{array}$ & $\begin{array}{c}0.210^{* *} \\
(0.11)\end{array}$ & $\begin{array}{l}0.105 \\
(0.10)\end{array}$ & $\begin{array}{c}0.528^{* *} \\
(0.26)\end{array}$ \\
\hline Read \& Write & $\begin{array}{c}0.343^{* *} \\
(0.15)\end{array}$ & $\begin{array}{c}0.337^{* * *} \\
(0.08)\end{array}$ & $\begin{array}{c}0.334^{* * *} \\
(0.06)\end{array}$ & $\begin{array}{c}0.627^{* * *} \\
(0.17)\end{array}$ \\
\hline Credit & $\begin{array}{r}-0.012 \\
(0.19)\end{array}$ & $\begin{array}{c}-0.191^{*} \\
(0.11)\end{array}$ & & \\
\hline Shock & $\begin{array}{c}-0.357^{* *} \\
(0.15)\end{array}$ & $\begin{array}{c}-0.403^{* * *} \\
(0.08)\end{array}$ & $\begin{array}{c}-0.132^{* *} \\
(0.07)\end{array}$ & $\begin{array}{c}-0.283 \\
(0.20)\end{array}$ \\
\hline Distance & $\begin{array}{r}-0.228 \\
(0.32)\end{array}$ & $\begin{array}{c}0.522^{* * *} \\
(0.17)\end{array}$ & $\begin{array}{r}-0.246 \\
(0.16)\end{array}$ & $\begin{array}{c}-1.989^{* * *} \\
(0.61)\end{array}$ \\
\hline Firm Size & $\begin{array}{c}-0.190^{* *} \\
(0.08) \\
\end{array}$ & $\begin{array}{l}0.018 \\
(0.02) \\
\end{array}$ & $\begin{array}{c}-0.148^{* * *} \\
(0.03) \\
\end{array}$ & $\begin{array}{r}-0.018 \\
(0.03) \\
\end{array}$ \\
\hline \multicolumn{5}{|l|}{ NFE } \\
\hline Number of Adults & $\begin{array}{l}0.035 \\
(0.02)\end{array}$ & $\begin{array}{c}0.114^{* * *} \\
(0.01)\end{array}$ & $\begin{array}{c}0.140^{* * *} \\
(0.02)\end{array}$ & $\begin{array}{c}0.065^{* * *} \\
(0.01)\end{array}$ \\
\hline Rural & $\begin{array}{c}-1.025^{* * *} \\
(0.09)\end{array}$ & $\begin{array}{c}-0.434^{* * *} \\
(0.06)\end{array}$ & $\begin{array}{c}-0.478^{* * *} \\
(0.05)\end{array}$ & $\begin{array}{c}-0.384^{* * *} \\
(0.09)\end{array}$ \\
\hline Female & $\begin{array}{l}0.110 \\
(0.09)\end{array}$ & $\begin{array}{r}-0.052 \\
(0.04)\end{array}$ & $\begin{array}{c}-0.163^{* *} \\
(0.07)\end{array}$ & $\begin{array}{r}-0.032 \\
(0.06)\end{array}$ \\
\hline Age: 25 to 34 & $\begin{array}{l}0.143 \\
(0.15)\end{array}$ & $\begin{array}{c}0.159^{* * *} \\
(0.06)\end{array}$ & $\begin{array}{c}0.357^{* *} \\
(0.16)\end{array}$ & $\begin{array}{c}0.382^{* *} \\
(0.19)\end{array}$ \\
\hline Age: 35 to 44 & $\begin{array}{l}0.066 \\
(0.16)\end{array}$ & $\begin{array}{c}0.140^{* *} \\
(0.06)\end{array}$ & $\begin{array}{c}0.551^{* * *} \\
(0.16)\end{array}$ & $\begin{array}{l}0.233 \\
(0.19)\end{array}$ \\
\hline Age: 45 and older & $\begin{array}{l}-0.179 \\
(0.15)\end{array}$ & $\begin{array}{c}-0.135^{* *} \\
(0.06)\end{array}$ & $\begin{array}{c}0.283^{*} \\
(0.15)\end{array}$ & $\begin{array}{l}0.006 \\
(0.18)\end{array}$ \\
\hline Read \& Write & $\begin{array}{c}0.206^{* * *} \\
(0.08)\end{array}$ & $\begin{array}{c}0.252^{* * *} \\
(0.04)\end{array}$ & $\begin{array}{c}0.195^{* * *} \\
(0.05)\end{array}$ & $\begin{array}{l}0.064 \\
(0.05)\end{array}$ \\
\hline Credit & $\begin{array}{c}0.342^{* * *} \\
(0.08)\end{array}$ & $\begin{array}{c}0.257^{* * *} \\
(0.05)\end{array}$ & & \\
\hline Shock & $\begin{array}{l}0.068 \\
(0.07)\end{array}$ & $\begin{array}{c}0.080^{* *} \\
(0.04)\end{array}$ & $\begin{array}{l}-0.028 \\
(0.05)\end{array}$ & $\begin{array}{l}0.042 \\
(0.07)\end{array}$ \\
\hline Distance & $\begin{array}{c}-0.369^{* * *} \\
(0.13)\end{array}$ & $\begin{array}{c}-0.315^{* * *} \\
(0.09)\end{array}$ & $\begin{array}{l}-0.080 \\
(0.13)\end{array}$ & $\begin{array}{l}0.324 \\
(0.20)\end{array}$ \\
\hline Agro-Ecological Zones & Yes & Yes & Yes & Yes \\
\hline $\mathrm{N}$ & 3,892 & 12,496 & 5,859 & 2,477 \\
\hline rho & -0.289 & -0.600 & -0.421 & -0.936 \\
\hline sigma & 1.568 & 1.484 & 1.339 & 3.064 \\
\hline lambda & -0.453 & -0.891 & -0.563 & -2.869 \\
\hline Prob > chi2 & 0.268 & 0.000 & 0.000 & 0.000 \\
\hline
\end{tabular}

Standard errors in parentheses; Household weights included; Coefficients reported.

${ }^{*} p<0.1,{ }^{* *} p<0.05,{ }^{* * *} p<0.01$ 
Second we analyze the variables of the outcome stage, associated with labor productivity. For the outcome stage we take the individual characteristics of the enterprise owner and add firm size to the regressions to include enterprise characteristics, while the remaining variables remain the same as in the selection stage. The age categories show significant effects on labor productivity in Malawi and Uganda, reporting positive coefficients for older age cohorts, and confirming our expectations that young entrepreneurs operate less productive enterprises. In these two countries older age cohort report a higher labor productivity of 20 to 30 percent compared to young entrepreneurs in Malawi and of 30 to 60 percent in Uganda, conditional on entering the non-farm business sector. However, we do not find significant effects of age in Ethiopia and Nigeria.

Among the remaining variables, we find that the enterprise location in a rural area has a significant and negative effect in Malawi and Nigeria, as well as the gender of the enterprise owner in Ethiopia, Malawi and Nigeria. If the enterprise owner is female, labor productivity is lower compared to male-owned enterprises. The ability to read \& write, a proxy for education, shows a significant and positive effect in all countries, increasing labor productivity. The effect of access to credit is marginally significant and negative in Malawi, a counter intuitive outcome to what we expected. While access to credit increases the probability of operating an enterprise in the first stage, it seems to reduce labor productivity once the enterprise is in operation in Malawi. A possible explanation could be that households who take out credit are more risk-averse in their choice of business activity and decide to operate less risky, but also less productive businesses. A surprising outcome is also the significant and negative effect of firm size in Ethiopia and Nigeria. As expected, the effect of shocks is significant and negative in Ethiopia, Malawi, and Nigeria. Finally, the effect of distance on labor productivity can go in both directions. It is significant and positive in Malawi, but significant and negative in Uganda. While the negative effect of Uganda is expected, the positive coefficient in Malawi suggests deep rural isolation of enterprises, possibly shielding them from external competition.

Summarizing the results of the age categories in the Heckman selection model, we identify significant and positive effects on enterprise operation among older age cohorts in the first stage (with the exception of Ethiopia), and significant and positive effects on labor productivity in the second stage in Malawi and Uganda. These results confirm our expectations that younger household heads are less likely to operate a non-farm enterprises, and that younger enterprise owners operate less productive businesses.

\subsubsection{Panel Data Analysis}

In the panel data analysis we make use of panel data from Nigeria and Uganda, and estimate three regressions for each country: first an ordinary least square regression where we hold the wave constant, second a regression including fixed effects, and third a regression including random effects.

Table 3 reports the results of the panel data analysis. The specification includes, apart from the age categories, a binary location variable, gender, the ability to read and write, number of adults in the household, experience of a shock, use of credit to expand the 
business and firm size. For Uganda we further add the variables migration and months in operation. The individual characteristics are taken from the enterprise owner.

Table 3: Panel Analysis

\begin{tabular}{|c|c|c|c|c|c|c|}
\hline \multirow[t]{2}{*}{ (ln) Productivity } & \multicolumn{3}{|c|}{ Nigeria } & \multicolumn{3}{|c|}{ Uganda } \\
\hline & OLS & $\mathrm{FE}$ & $\mathrm{RE}$ & OLS & FE & $\mathrm{RE}$ \\
\hline Rural & $\begin{array}{c}-0.436^{* * *} \\
(0.05)\end{array}$ & $\begin{array}{c}-0.936^{* * *} \\
(0.26)\end{array}$ & $\begin{array}{c}-0.427^{* * *} \\
(0.04)\end{array}$ & $\begin{array}{c}-0.454^{* * *} \\
(0.15)\end{array}$ & $\begin{array}{r}-0.137 \\
(0.48)\end{array}$ & $\begin{array}{c}-0.661^{* * *} \\
(0.08)\end{array}$ \\
\hline Female & $\begin{array}{c}-0.583^{* * *} \\
(0.04)\end{array}$ & $\begin{array}{c}-0.748^{* * *} \\
(0.04)\end{array}$ & $\begin{array}{c}-0.669^{* * *} \\
(0.03)\end{array}$ & $\begin{array}{c}-0.427^{* * *} \\
(0.11)\end{array}$ & $\begin{array}{c}-0.608^{* * *} \\
(0.11)\end{array}$ & $\begin{array}{c}-0.653^{* * *} \\
(0.07)\end{array}$ \\
\hline Age: 25 to 34 & $\begin{array}{c}0.220^{* * *} \\
(0.07)\end{array}$ & $\begin{array}{c}0.106^{*} \\
(0.06)\end{array}$ & $\begin{array}{c}0.197^{* * *} \\
(0.05)\end{array}$ & $\begin{array}{c}0.484^{* *} \\
(0.22)\end{array}$ & $\begin{array}{c}0.620^{* * *} \\
(0.19)\end{array}$ & $\begin{array}{c}0.644^{* * *} \\
(0.14)\end{array}$ \\
\hline Age: 35 to 44 & $\begin{array}{c}0.373^{* * *} \\
(0.07)\end{array}$ & $\begin{array}{c}0.262^{* * * *} \\
(0.07)\end{array}$ & $\begin{array}{c}0.328^{* * *} \\
(0.05)\end{array}$ & $\begin{array}{l}0.357 \\
(0.23)\end{array}$ & $\begin{array}{c}0.694^{* * * *} \\
(0.22)\end{array}$ & $\begin{array}{c}0.636^{* * * *} \\
(0.14)\end{array}$ \\
\hline Age: 45 and older & $\begin{array}{c}0.404^{* * *} \\
(0.07)\end{array}$ & $\begin{array}{c}0.300^{* * * *} \\
(0.07)\end{array}$ & $\begin{array}{c}0.350^{* * *} \\
(0.05)\end{array}$ & $\begin{array}{l}-0.002 \\
(0.23)\end{array}$ & $\begin{array}{c}0.519^{* * * *} \\
(0.17)\end{array}$ & $\begin{array}{c}0.278^{* *} \\
(0.14)\end{array}$ \\
\hline Read \& Write & $\begin{array}{c}0.425^{* * *} \\
(0.04)\end{array}$ & $\begin{array}{c}0.115^{* *} \\
(0.06)\end{array}$ & $\begin{array}{c}0.306^{* * *} \\
(0.04)\end{array}$ & $\begin{array}{c}0.775^{* * *} \\
(0.14)\end{array}$ & $\begin{array}{l}-0.140 \\
(0.14)\end{array}$ & $\begin{array}{c}0.409^{* * * *} \\
(0.08)\end{array}$ \\
\hline Migration & & & & $\begin{array}{l}0.233^{*} \\
(0.12)\end{array}$ & $\begin{array}{l}0.149 \\
(0.11)\end{array}$ & $\begin{array}{c}0.234^{* * * *} \\
(0.07)\end{array}$ \\
\hline Number of Adults & $\begin{array}{c}0.027^{* *} \\
(0.01)\end{array}$ & $\begin{array}{l}-0.037 \\
(0.04)\end{array}$ & $\begin{array}{l}0.010 \\
(0.01)\end{array}$ & $\begin{array}{c}0.112^{* * *} \\
(0.02)\end{array}$ & $\begin{array}{c}0.088^{* * *} \\
(0.03)\end{array}$ & $\begin{array}{c}0.115^{* * *} \\
(0.02)\end{array}$ \\
\hline Shock & $\begin{array}{c}-0.141^{* * *} \\
(0.05)\end{array}$ & $\begin{array}{l}0.122^{*} \\
(0.07)\end{array}$ & $\begin{array}{l}-0.027 \\
(0.04)\end{array}$ & $\begin{array}{c}-0.192^{*} \\
(0.11)\end{array}$ & $\begin{array}{l}-0.074 \\
(0.08)\end{array}$ & $\begin{array}{c}-0.228^{* * *} \\
(0.06)\end{array}$ \\
\hline Credit & $\begin{array}{c}0.445^{* * *} \\
(0.06)\end{array}$ & $\begin{array}{c}0.243^{* * *} \\
(0.07)\end{array}$ & $\begin{array}{c}0.381^{* * *} \\
(0.05)\end{array}$ & $\begin{array}{c}0.814^{* * *} \\
(0.10)\end{array}$ & $\begin{array}{c}0.457^{* * *} \\
(0.11)\end{array}$ & $\begin{array}{c}0.676^{* * * *} \\
(0.07)\end{array}$ \\
\hline Firm Size & $\begin{array}{c}-0.110^{* * *} \\
(0.03)\end{array}$ & $\begin{array}{c}-0.124^{* * *} \\
(0.04)\end{array}$ & $\begin{array}{c}-0.094^{* * *} \\
(0.03)\end{array}$ & $\begin{array}{r}-0.016 \\
(0.03)\end{array}$ & $\begin{array}{c}-0.114^{* * *} \\
(0.02)\end{array}$ & $\begin{array}{c}-0.058^{* * *} \\
(0.02)\end{array}$ \\
\hline Months in Operation & & & & $\begin{array}{c}0.117^{* * *} \\
(0.02)\end{array}$ & $\begin{array}{c}0.059^{* * *} \\
(0.02)\end{array}$ & $\begin{array}{c}0.078^{* * *} \\
(0.01)\end{array}$ \\
\hline Constant & $\begin{array}{c}8.417^{* * *} \\
(0.12)\end{array}$ & $\begin{array}{c}9.299^{* * *} \\
(0.21) \\
\end{array}$ & $\begin{array}{c}8.586^{* * *} \\
(0.11)\end{array}$ & $\begin{array}{c}8.996^{* * *} \\
(0.33)\end{array}$ & $\begin{array}{c}10.028^{* * *} \\
(0.45)\end{array}$ & $\begin{array}{c}9.657^{* * *} \\
(0.24)\end{array}$ \\
\hline Time FE & Yes & Yes & Yes & Yes & Yes & Yes \\
\hline $\mathrm{FE}$ & No & Yes & No & No & Yes & No \\
\hline $\mathrm{RE}$ & No & No & Yes & No & No & Yes \\
\hline $\mathrm{R}^{2}$ & 0.163 & 0.115 & 0.147 & 0.165 & 0.108 & 0.173 \\
\hline $\mathrm{N}$ & 7,755 & 7,755 & 7,786 & 4,501 & 4,501 & 4,506 \\
\hline
\end{tabular}

Standard errors in parentheses; Household weights included.

${ }^{*} p<0.1,{ }^{* *} p<0.05,{ }^{* * *} p<0.01$

The effect of age is significant and positive for almost all regressions and age categories. The only exception is the OLS regression using data from Uganda, where only the age category 25 to 34 is significant. The differences range between 10 to 40 percent in Nigeria, and between 28 to almost 70 percent in Uganda. Overall we can firmly say that age does have a positive effect on labor productivity over time in Nigeria and Uganda.

We further find that individual characteristics of the enterprise owner are highly significant. The effect of location is significant and negative for most regression results in both countries, and shows lower labor productivity in enterprises located in rural areas. The effect for gender is significant and negative in all regressions. Women-owned enterprise have a lower labor productivity compared to male-owned enterprises. The ability to read and write, a proxy for education, is significant and positive for most 
regressions, increasing labor productivity of the enterprise. The effect of migration is significant and positive in the OLS and RE regressions.

The significance of the effects of household characteristics vary. The number of adults in a household significantly increases labor productivity in Uganda per additional household member. In Nigeria we only find a significant effect in the OLS regression. The effect of shocks is significant in some of the regressions, and the coefficients report in their majority a negative effect, where significant.

Finally we report the effects of enterprise characteristics. The effect of credit used to expand the business has a significant and positive effect on labor productivity in all regressions. The variable months of enterprise operation, indicating the months of enterprise operation over the past 12 months, is significant and positive in Uganda. For each additional months an enterprise operation throughout the year labor productivity is expected to increase, indicating a better capacity utilization of the firm.

Summarizing this section, we find that enterprise owners belonging to a middle-age or older age category show significantly higher levels of labor productivity in both countries. Compared to the Heckman selection model, taking the age of the enterprise owner and conducting the analysis over time introducing fixed and random effects, shows that age does have a significant and positive effect on labor productivity not only in Uganda, but also in Nigeria.

\section{$5 \quad$ Summary and Concluding Remarks}

In this paper we present for the first time empirical evidence on (i) the prevalence and contribution, (ii) determinants of enterprise operation, and (iii) labor productivity of young entrepreneurs in rural Africa using the World Bank's recent LSMS-ISA data set. Our results confirm that non-farm entrepreneurship is more prevalent among middle-aged than young adults and that households with young heads derive a smaller share of total household income from self-employment. We also find that Africa's young population is less likely to operate an enterprise than older adults. Finally we find that enterprises owned by young entrepreneurs are less productive, also when controlling for individual, household and firm characteristics. In the remaining section we first present the results of our paper in more detail, before discussing conclusions in the second part.

First, we find that young enterprise owners present a lower share among the self-employed and that this difference is particularly pronounced in Tanzania, where less than 5 percent of all enterprise owners are younger than 25 compared to almost 40 percent in the following age cohort. In Ethiopia the shares are more equally distributed, but the middle-aged cohorts are also more prevalent among enterprise owners. Consequently the share of total household income derived from self-employment is lower if the household head is younger than 25 years, with differences between 3 to 12 percentage points compared to the next older age cohort. Second, we establish that age is a significant factor to explain enterprise operation. In Malawi, Nigeria and Uganda, middle-age household heads have 
a significantly higher likelihood of operating a non-farm enterprise, which varies from 4 to 18 percent points compared to the reference group (younger than 25 years). Among household heads who are aged 45 or older, the pattern is inconsistent and shows both a higher and lower likelihood, as well as insignificant outcomes. Third, we show that labor productivity varies by age group and that young entrepreneurs operate enterprises with lower productivity compared to middle and older aged enterprise owners. While the differences appear to be small in the kernel density estimates, we find significant outcomes by age category in the regression results. In the Heckman selection model the age categories are significant and positive in Malawi and Uganda, where older age cohort report a higher labor productivity of 20 to 60 percent compared to young entrepreneurs, conditional on entering the non-farm business sector. In the panel data analysis, we find that enterprise owners in the older age categories operate enterprises with higher labor productivity in both Nigeria and Uganda. The differences range between 10 to 40 percent in Nigeria, and between 28 to almost 70 percent in Uganda.

The conclusions based on these findings are twofold, given the challenge to provide employment for millions of young job seekers in rural Africa and the potential for nonfarm entrepreneurship to create new employment. First, we suggest policies that create conditions to attract and facilitate non-farm entrepreneurship for young adults interested in entering this sector. Although the findings that young adults present a smaller share in the non-farm enterprise sector and show a lower likelihood of operating an enterprise do not necessarily imply exclusion or discrimination, as many young adults are still in education or pursuing other opportunities, potential entrepreneurs might still face obstacles to start an enterprise, such as lack of experience, training or access to finance. Second, once young entrepreneurs enter the rural non-farm economy, it is important to ensure that they operate enterprises that are productive and have the potential grow. This would require an environment where they can build up assets and gain relevant experience and training to move into higher productivity type of activities. It also implies an environment where they are less exposed to incomplete markets and external shocks, for example through micro insurance schemes or the implementation of social safety nets. Given the numbers of potential young entrepreneurs, the efficiency gains for dealing with incomplete or missing markets and limited social protection could be substantial. If more young adults enter the non-farm sector to start enterprises, and if these enterprises grow and survive, they have the potential to provide part of the employment urgently needed in Africa's rural areas for the increasing number of young labor market entrants over the coming years.

Our paper provides a first, explorative analysis of young entrepreneurs in rural Africa, but calls for more and better research in this area. One of the principal shortcomings of the current analysis is due to data availability. While the LSMS-ISA database offers a rich data set, including a separate section on non-farm entrepreneurship, we face a number of data challenges. First, the differences in the questionnaires of the countries studied only allows for limited comparability, as certain variables or formulation of questions can be found in one, but not in the other questionnaire(s). Second, our measure of productivity is partial and imprecise. And third, useful variables and information are lacking and therefore limiting us in our analysis. For example the possibility to match the type of business activity with enterprise information, or more detailed information of enterprises that stopped operating in order to conduct survival analysis. More and better data needs 
to be collected for a more exhaustive and in-depth analysis of the non-farm enterprise sector. Given the need for rural employment of the young population, access to the non-farm business sector and faster productivity growth have the potential to facilitate employment creation and structural transformation in Africa. The benefits of obtaining improved data may be worth the effort. 


\section{Acknowledgements}

We are particularly grateful to Luc Christiaensen for his inspiration, many stimulating discussions and useful comments. We also wish to thank Richard Bluhm, Brian Dillon, Jonathan Kaminski, Amparo Palacios-López, Bob Rijkers, Omar Rodríguez-Torres, Alberto Zezza and other participants at workshops and conferences in Brussels, Lima, Lusaka, Maastricht, Paris and Washington DC. We gratefully acknowledge the comments of an anonymous reviewer. The usual disclaimer applies. 


\section{References}

Abdulai, A. and Delgado, C. (1999). Determinants of Non-Farm Earnings of Farm-Based Husbands and Wives in Northern Ghana. American Journal of Agricultural Economics, $81(1): 117-130$.

Ackah, C. (2013). Non-Farm Employment and Income in Rural Ghana. Journal of International Development, 25:325-339.

Arnold, J., Mattoo, A., and Narciso, G. (2006). Services Inputs and Firm Productivity in Sub-Saharan Africa: Evidence from Firm-Level Data. World Bank Policy Research Working Paper No. 4048, Washington DC: The World Bank.

Babatunde, R. and Qaim, M. (2010). Impact of Off-Farm Income on Food Security and Nutrition in Nigeria. Food Policy, 35:303-311.

Barrett, C., Reardon, T., and Webb, P. (2001). Non-Farm Income Diversification and Household Livelihood Strategies in Rural Africa: Concepts, Issues, and Policy Implications. Food Policy, 26 (4):315-331.

Bezu, S. and Barrett, C. (2012). Employment Dynamics in the Rural Non-Farm Sector in Ethiopia: Do the Poor Have Time on their Side? Journal of Development Studies, 48(9):1223-1240.

Bhaumik, S., Dimova, R., and Nugent, J. (2011). Off-Farm Labor Supply and Labor Markets in Rapidly Changing Circumstances: Bulgaria during Transition. Economic Systems, 35:378-389.

Blattmann, C., Fiala, N., and Martinez, S. (2014). Generating Skilled Self-Employment in Developing Countries: Experimental Evidence from Uganda. Quarterly Journal of Economics, 129 (2):697-752.

Carletto, G., Covarrubias, K., Davis, B., Krausova, M., and Winters, P. (2007). Rural Income Generating Activities Study: Methodological Note on the Construction of Income Aggregates. Technical report, FAO.

Davis, B., Winters, P., Carletto, G., Covarrubias, K., Quinones, E., Zezza, A., Stamoulis, K., Bonomi, G., and DiGuiseppe, S. (2010). A Cross-Country Comparison of Rural Income Generating Activities. World Development, 38 (1):48-63.

Davis, J. and Bezemer, D. (2004). The Development of the Rural Non-Farm Economy in Developing Countries and Transition Economies: Key Emerging and Conceptual Issues. Chatham, UK: Natural Resources Institute.

Dercon, S. (2009). Rural Poverty: Old Challenges in New Contexts. World Bank Research Observer, 24(1):1-28.

Dethier, J., Hirn, M., and Straub, S. (2010). Explaining Enterprise Performance in Developing Countries with Business Climate Survey Data. World Bank Research Observer, 26:258-309.

DIAL (2007). Youth and Labor Markets in Africa: A Critical Review of the Literature. Working Paper DT/2007-02. 
Dollar, D., Hallword-Driemeier, M., and Mengistae, T. (2005). Investment Climate and Firm Performance in Developing Countries. Economic Development and Cultural Change, 54 (1):1-31.

Eifert, B., Gelb, A., and Ramachandran, V. (2008). The Cost of Doing Business in Africa: Evidence from Enterprise Survey Data. World Development, 36 (9):1531-1546.

Fox, L., Haines, G., Munoz, J., and Thomas, A. (2013). Africa's Got Work to Do: Employment Prospects in the New Century. IMF Working Paper No. 13.

Fox, L. and Pimhidzai, O. (2013). Household Non-Farm Enterprises and Structural Transformation: Evidence from Uganda. Paper presented at the UNU-WIDER Conference on Inclusive Growth in Africa, Helsinki.

Fox, L. and Sohnesen, T. (2013). Household Enterprises in Mozambique: Key to Poverty Reduction but not on the Development Agenda? Policy Research Working Paper No. 6570. Washington DC: The World Bank.

Frazer, G. (2005). Which Firms Die? A Look at Manufacturing Firm Exit in Ghana. Economic Development and Cultural Change, 53 (3):585-617.

Grindling, T. and Newhouse, D. (2014). Self-Employment in the Developing World. World Development, 56:313-331.

Havnevik, K., Haarsmar, M., and Sandström, E. (2003). Rural Development and the Private Sector in Sub-Saharan Africa: SIDA's Experiences and Approaches in the 1990s. Stockholm: SIDA Evaluation 03/18.

Lanjouw, J. and Lanjouw, P. (2001). The Rural Non-Farm Sector: Issues and Evidence from Developing Countries. Agricultural Economics, 26:1-23.

Leavy, J. and Smith, S. (2010). Future Farmers: Youth Aspirations, Expectations and Life Choices. FAC Discussion Paper No. 13, Future Agricultures.

Lewis, W. (1954). Economic Development with Unlimited Supplies of Labour. The Manchester School.

McArthur, J. (2014). Pushing the Employment Frontiers for Africa's Rural and Urban Youth. The Brookings Institution: Africa Growth Initiative.

Nagler, P. and Naudé, W. (2014a). Labor Productivity in Rural African Enterprises: Empirical Evidence from the LSMS-ISA. IZA Discussion Paper No. 8524.

Nagler, P. and Naudé, W. (2014b). Non-Farm Entrepreneurship in Rural Africa: Patterns and Determinants. IZA Discussion Paper No. 8008.

Namatovu, R., Dawa, S., Mulira, F., Katongole., C., and Nyongesa, S. (2012). Rural Youth Entrepreneurs in East Africa: A View from Uganda and Kenya. ICBE-RF Research Report No. 32/12.

Naudé, W. (2011). Entrepreneurship is not a Binding Constraint on Growth and Development in the Poorest Countries. World Development, 39 (1):33-44. 
Owoo, N. and Naudé, W. (2014). Non-Farm Enterprise Performance and Spatial Autocorrelation in Rural Africa: Evidence from Ethiopia and Nigeria. IZA Discussion Paper No. 8295.

Pieters, J. (2013). Youth Employment in Developing Countries. IZA Research Report No. 58.

Potts, D. (2012). Challenging the Myths of Urban Dynamics in Sub-Saharan Africa: The Evidence from Nigeria. World Development, 40(7):1382 - 1393.

Pye-Smith, C. (2012). Increasing Rural Employment in Sub-Saharan Africa. CTA Policy Brief No. 4.

Reardon, T. (1997). Using Evidence of Household Income Diversification to Inform Study of the Rural Non-Farm Labor Market in Africa. World Development, 25 (5):735-747.

Reardon, T., Berdegue, J., Barrett, C., and Stamoulis, K. (2006). Household Income Diversification into Rural Non-Farm Activities. Baltimore: Johns Hopkins University Press.

Rijkers, B. and Costa, R. (2012). Gender and Rural Non-Farm Entrepreneurship. World Development, 40 (12):2411-2426.

Rijkers, B. and Söderbom, M. (2013). The Effects of Risk and Shocks on Non-Farm Enterprise Development in Rural Ethiopia. World Development, 45:119-136.

Rijkers, B., Söderbom, M., and Loening, J. (2010). A Rural-Urban Comparison of Manufacturing Enterprise Performance in Ethiopia. World Development, 38 (9):12781296.

Roepstorff, T. and Wiggens, S. (2011). New Global Realities Governing Agribusiness. UNIDO: Vienna.

Söderbom, M. and Teal, F. (2004). Size and Efficiency in African Manufacturing Firms: Evidence from Firm-Level Panel Data. Journal of Development Economics, 73 (1):369394.

Söderbom, M., Teal, F., and Harding, A. (2006). The Determinants of Survival among African Manufacturng Firms. Economic Development and Cultural Change, 54 (3):533555 .

Start, D. (2001). The Rise and Fall of the Rural Non-Farm Economy: Poverty Impacts and Policy Options. Development Policy Review, 19 (4):491-505.

Syverson, C. (2011). What Determines Productivity? Journal of Economic Literature, 49 (2):326-365.

Teal, F. (2014). Employment Creation, Poverty and the Structure of the Job Market in Nigeria. CSAE Working Paper WPS 2014/18.

van der Geest, K. (2010). Rural Youth Employment in Developing Countries: A Global View. FAO Overview No. 1, Rome: Food and Agricultural Organization.

Wiggens, S. (2000). Interpreting Changes from the 1970s to the 1990s in African Agriculture through Village Studies. World Development, 28 (4):631-662. 


\section{A Appendix: Data Manipulation}

\section{$\underline{\text { All Estimates }}$}

We replace the age of the household head or enterprise owner with the median age in case the age variable is missing, below 15 or above 99. This happens however only for very few observations.

$\underline{\text { Panel Data Analysis }}$

Households are visited and interviewed during the first survey round, and households operating a non-farm enterprise are registered in the respective section. Due to the panel design, the same households are visited again in the consecutive survey rounds. If a household of the previous round is no longer operating an enterprise, the household is still registered in the respective section, but does not fill out the questions on nonfarm entrepreneurship. Therefore it is possible to identify the enterprises that were discontinued since the last survey round if the enterprises can clearly be tracked over the waves. If not, it is possible to know the number of enterprises that were discontinued. In Uganda, various "empty" observations in follow-up surveys do not have observations in the previous survey round(s), and we decide to exclude these observations, as it is not clear what kind of information they present, if they are discontinued enterprises or false observations. We delete 82 out of 7,985 observations, resulting in a final database of 7,903 enterprises for the panel data analysis. We do not encounter this issue in Nigeria.

Further data manipulation includes the following: prices are inflation deflated to prices of the first survey round of the respective country, using the IMF's inflation index of average consumer prices (percentage change). Furthermore prices are "winsorized" at 1 percent. We also "winsorize" the number of employees at 1 percent. We further replace a few outlier values, for example if the months in operation exceeded 12 months. 


\section{B Appendix: Summary Statistics}

\section{B.1 Age Categories}

Table 4: Summary Statistics - Age Categories

\begin{tabular}{lcccccc}
\hline & Ethiopia & Malawi & Niger & Nigeria & Tanzania & Uganda \\
\hline Younger than 25 & 196 & 220 & 281 & 234 & 3 & 105 \\
Age: 25 to 34 & 338 & 695 & 628 & 697 & 35 & 312 \\
Age: 35 to 44 & 260 & 480 & 549 & 762 & 31 & 344 \\
Age: Older than 45 & 178 & 472 & 729 & 941 & 24 & 319 \\
Total & 972 & 1,867 & 2,187 & 2,634 & 93 & 1,080 \\
\hline
\end{tabular}

Notes: Rural areas only. 


\section{B.2 Heckman Selection Model}

Table 5: Summary Statistics - Heckman Selection Model

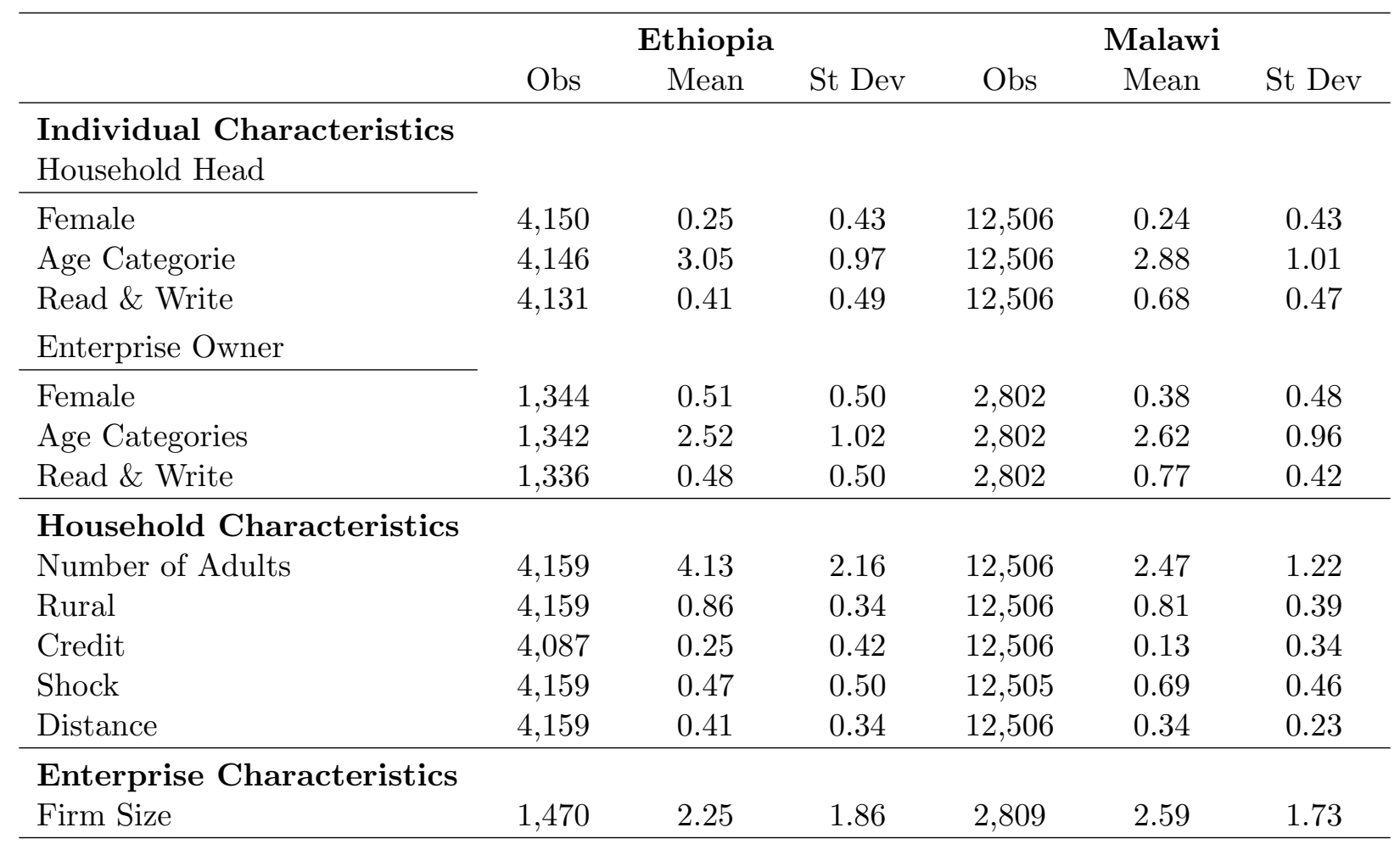

Table 6: Summary Statistics - Heckman Selection Model

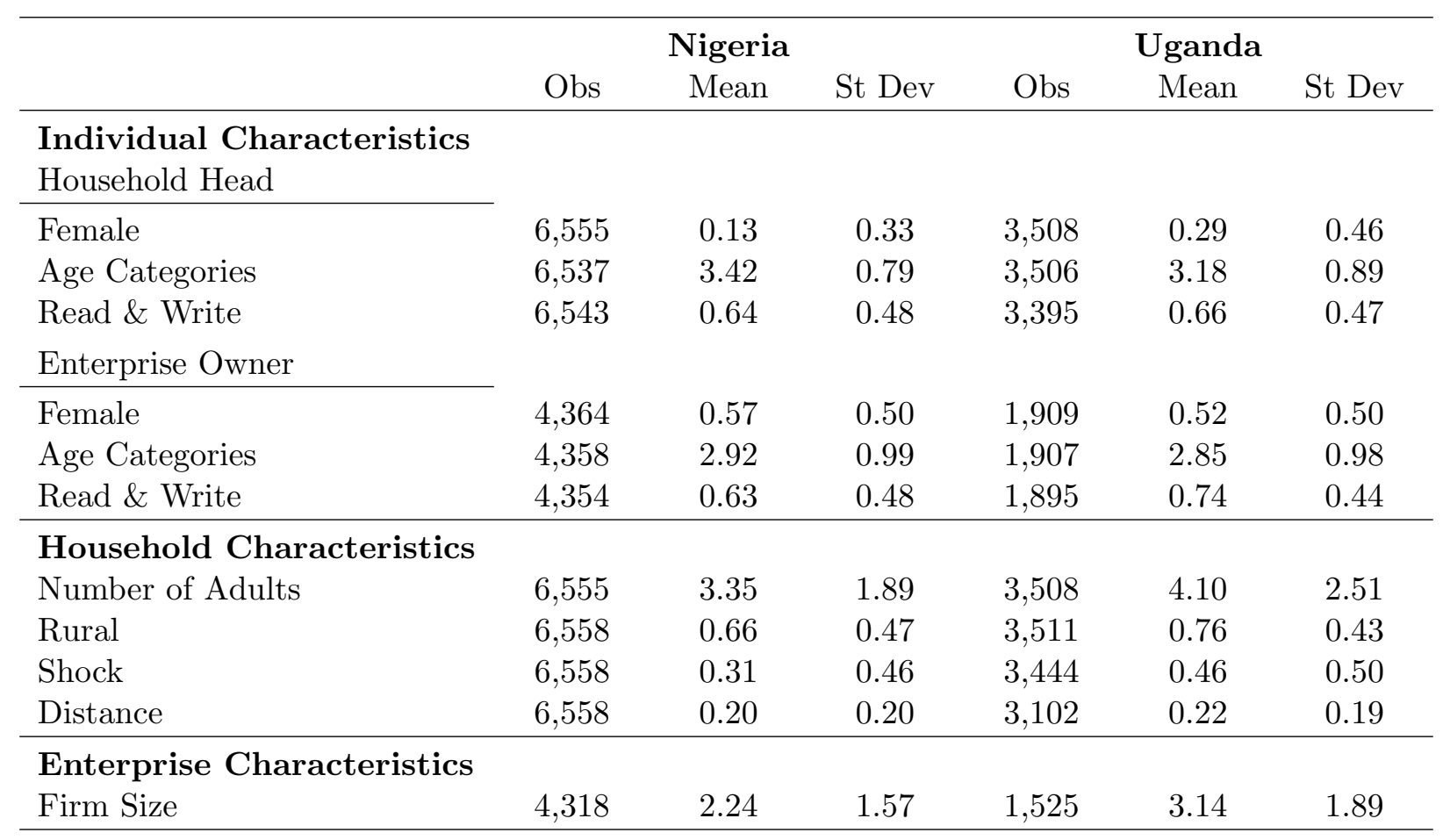




\begin{tabular}{ll}
\hline Female & 1 if female. \\
Age & The age categories are defined as: 15 to $24=1,25$ to $34=2$, \\
& 35 to $44=3,45$ and older $=4$. \\
Read \& Write & 1 if individual can read and write in any language. \\
Number of Adults & Number of adults age 15 or older in the household. \\
Rural & 1 if household is located in a rural area. \\
Credit & 1 if household has access to credit. This variable is defined as \\
& general access to credit and does not further specify for which \\
& purpose the household used it. \\
Shock & (e.g. death or illness of a household member), related to prices \\
& (e.g. increase in the price level of certain goods and services), \\
& related to agriculture (e.g. droughts or floods), or other types \\
& of shocks (not further specified in the questionnaire). \\
& Defined as distance to next population center of 20,000 or more \\
& inhabitants, in 100's of km. \\
& Number of workers in the enterprise. \\
Distance & Tropic-warm or tropic-cool, combined with different \\
precipitation levels: arid, semi arid, sub humid, humid. & \\
Firm Size &
\end{tabular}




\section{B.3 Panel Data Analysis}

Table 7: Summary Statistics - Panel Data Analysis

\begin{tabular}{lcccccc}
\hline & \multicolumn{3}{c}{$\begin{array}{c}\text { Nigeria } \\
\text { Mean }\end{array}$} & St Dev & Obs & Uganda \\
& Obs & Mean & St Dev \\
\hline Individual Characteristics & & & & & & \\
Female & 8,715 & 0.56 & 0.50 & 4,686 & 0.49 & 0.50 \\
Age Categories & 8,711 & 2.96 & 0.99 & 4,684 & 2.83 & 0.98 \\
Read \& Write & 8,687 & 0.64 & 0.48 & 4,530 & 0.75 & 0.43 \\
Migration & & & 4,796 & 0.64 & 0.48 \\
\hline Household Characteristics & & & & & & \\
Rural & 8,715 & 0.62 & 0.49 & 4,795 & 0.71 & 0.45 \\
Number of Adults & 8,715 & 3.90 & 2.15 & 4,686 & 3.71 & 2.16 \\
Shock & 8,715 & 0.24 & 0.43 & 4,796 & 0.48 & 0.50 \\
\hline Enterprise Characteristics & & & & & & \\
Credit & 8,666 & 0.08 & 0.26 & 4,785 & 0.12 & 0.33 \\
Firm Size & 8,715 & 2.21 & 2.06 & 4,796 & 4.04 & 2.28 \\
Months in Operation & & & & 4,779 & 9.59 & 3.49 \\
\hline
\end{tabular}

\section{Definition of Variables for the Panel Data Analysis}

Female 1 if female.

Age Categories

The age categories are defined as: 15 to $24=1,25$ to $34=2$,

Read \& Write 35 to $44=3,45$ and older $=4$.

Migration 1 if individual can read and write in any language.

1 if individual migrated. It indicates if the individual moved from another district or country to the current place of

Rural residence.

Number of Adults 1 if household is located in a rural area.

Shock

Number of adults age 15 or older in the household.

1 if household experienced a shock. Shocks can be idiosyncratic (e.g. death or illness of a household member), related to prices (e.g. increase in the price level of certain goods and services), related to agriculture (e.g. droughts or floods), or other types of shocks (not further specified in the questionnaire).

Credit 1 if household has taken out credit to expand the business. The use of credit is clearly related to the purpose of operating and expanding the business, and not used for other purposes within the household.

Firm Size Number of workers in the enterprise.

Months in Operation Number of months the enterprise was in operation during the past 12 months (max. 12). 


\section{Appendix: Marginal Effects}

Table 8: Marginal Effects - Heckman Selection Model

\begin{tabular}{lcccc}
\hline & $\begin{array}{c}\text { Ethiopia } \\
(1)\end{array}$ & $\begin{array}{c}\text { Malawi } \\
(2)\end{array}$ & $\begin{array}{c}\text { Nigeria } \\
(3)\end{array}$ & $\begin{array}{c}\text { Uganda } \\
(4)\end{array}$ \\
\hline NFE & & & & \\
Age: 25 to 34 & 0.044 & $0.049^{* * *}$ & $0.118^{* *}$ & $0.147^{* *}$ \\
& $(0.15)$ & $(0.02)$ & $(0.05)$ & $(0.07)$ \\
Age: 35 to 44 & 0.021 & $0.043^{* *}$ & $0.182^{* * *}$ & 0.090 \\
& $(0.05)$ & $(0.02)$ & $(0.05)$ & $(0.07)$ \\
Age: 45 and older & -0.055 & $-0.041^{* *}$ & $0.093^{*}$ & 0.002 \\
& $(0.06)$ & $(0.02)$ & $(0.05)$ & $(0.07)$ \\
\hline
\end{tabular}

Average marginal effects reported; Standard errors in parentheses.

${ }^{*} p<0.1,{ }^{* *} p<0.05,{ }^{* * *} p<0.01$ 